\title{
Seroprevalence of Rift Valley fever virus in livestock during inter-epidemic period in Egypt, 2014/15
}

\author{
Claudia Mroz ${ }^{1}$, Mayada Gwida², Maged El-Ashker ${ }^{3}$, Mohamed El-Diasty ${ }^{4}$, Mohamed El-Beskawy ${ }^{5}$, Ute Ziegler ${ }^{1}$, \\ Martin Eiden ${ }^{1}$ and Martin H. Groschup ${ }^{1 *}$
}

\begin{abstract}
Background: Rift Valley fever virus (RVFV) caused several outbreaks throughout the African continent and the Arabian Peninsula posing significant threat to human and animal health. In Egypt the first and most important Rift Valley fever epidemic occurred during 1977/78 with a multitude of infected humans and huge economic losses in livestock. After this major outbreak, RVF epidemics re-occurred in irregular intervals between 1993 and 2003. Seroprevalence of antiRVFV antibodies in livestock during inter-epidemic periods can be used for supporting the evaluation of the present risk exposure for animal and public health. A serosurvey was conducted during 2014/2015 in non-vaccinated livestock including camels, sheep, goats and buffalos in different areas of the Nile River Delta as well as the furthermost southeast of Egypt to investigate the presence of anti-RVFV antibodies for further evaluating of the risk exposure for animal and human health. All animals integrated in this study were born after the last Egyptian RVF epidemic in 2003 and sampled buffalos and small ruminants were not imported from other endemic countries.
\end{abstract}

Results: A total of 873 serum samples from apparently healthy animals from different host species (camels: $n=221$; sheep: $n=438$; goats: $n=26$; buffalo: $n=188$ ) were tested serologically using RVFV competition ELISA, virus neutralization test and/or an indirect immunofluorescence assay, depending on available serum volume. Sera were assessed positive when virus neutralization test alone or least two assays produced consistent positive results. The overall seroprevalence was $2.29 \%(95 \% \mathrm{Cl}: 1.51-3.07)$ ranging from $0 \%$ in goats, $0.46 \%$ in sheep $(95 \% \mathrm{Cl}: 0.41-0.5)$, and $3.17 \%$ in camels (95\%Cl: $0.86-5.48)$ up to $5.85 \%$ in buffalos (95\%Cl: $2.75-8.95$ ).

Conclusion: Our findings assume currently low level of circulating virus in the investigated areas and suggest minor indication for a new RVF epidemic. Further the results may indicate that during long inter-epidemic periods, maintenance of the virus occur in vectors and also most probably in buffaloes within cryptic cycle where sporadic, small and local epidemics may occur. Therefore, comprehensive and well-designed surveillance activities are urgently needed to detect first evidence for transition from endemic to epidemic cycle.

Keywords: Rift Valley fever virus, Livestock, Inter-epidemic period, Surveillance, Egypt

\section{Background}

Rift Valley fever is a mosquito-borne zoonotic disease in ruminants, camels and humans caused by Rift Valley fever virus (RVFV), a Phlebovirus within the family Bunyaviridae $[1,2]$. The viral disease was identified for the first time in 1930 in Kenya and is characterized by high fever and

\footnotetext{
* Correspondence: martin.groschup@fli.bund.de

${ }^{1}$ Institute of Novel and Emerging Infectious Diseases,

Friedrich-Loeffler-Institut, Südufer 10, 17493 Greifswald - Isle of Riems,

Germany

Full list of author information is available at the end of the article
}

abortion in livestock and high neonatal mortality mainly in sheep [3-6]. Infected humans show a mild febrile illness, however in $1-2 \%$ of cases the patients develop severe complications such as ocular disease, hemorrhagic fever syndrome or encephalitis [7]. Typically the general case fatality is low $(1-3 \%)$. But patients with hemorrhagic fever syndrome show fatality rates up to $50 \%$ [8].

It has been reported that more than 30 mosquito species from 6 genera can transmit the virus to susceptible hosts [7]. Bites of infected mosquitos play the most important 
role for ruminant infection $[7,9]$. The direct contact with infectious materials when handling with sick or dead infected animals, abortion material or other fresh tissues represents the main transmission route in humans. Due to climatic changes and high level livestock trade, the virus is widespread in Africa and spread also in 2000 to Saudi Arabia and Yemen $[5,9,10]$. Climatic and environmental conditions like heavy rainfalls with increasing mosquito population redound consistently to new RVF outbreaks. Severe outbreaks occurred for instance in Mauritania and in South Africa in 2010, in Kenya, Tanzania and Somalia in 2007 as well as in Sudan in 2008 and 2010 [11-14].

The RVFV was introduced to Egypt in 1977 and caused an extensive epidemic with thousands of infected humans, more than 600 deaths and high economic losses in livestock affecting five governorates in the Nile Delta (Sharqia, Aswan, Qalyubia, Giza and Assiut [5, 15-18]. Up to now, it has been considered the major outbreak for Egypt and one of the largest epidemics in the RVF history of Africa. After a long inter-epidemic period, the RVF re-occurred in the Nile Delta of Egypt in 1993 in Aswan and Damietta governorates [19-21]. Further outbreaks recurred in 1994 (Beheira and Kafr el Sheikh governorates) as well as in 1997 (Assuit and Aswan governorates) and most recently in 2003 (Kafr el Sheikh governorate) [19, 21-23]. The sources of the diverse outbreaks are broadly discussed but the maintenance of the virus during inter-epidemic periods is still poorly understood $[21,24]$. It has been reported that the presence of unvaccinated susceptible livestock in combination with favorable conditions for mosquito breeding and spread are facilitating conditions for the persistence of the RVFV in Egypt [21]. Detection of RVFV specific antibodies in non-immunized animals a long time after the last RVF epidemic indicates endemic maintenance of the virus in inter-epidemic periods and seroconversion often occurs without any clinical signs in the livestock population $[25,26]$.

Evidence of circulating virus in the current interepidemic phase has been found by Ramadan [27] in 2009 who proves the presence of anti-RVFV-antibodies in Dakahlia governorate in different livestock species ( sheep $=20 \%$, goats $=17 \%$, cattle $=5 \%$ and buffalos $=11 \%$ respectively). An additional survey from Marawan [28] in 2012 shows related prevalence rates in nonimmunized sheep, goats, camels, cattle and buffalos (17, 7, 0, 19 and 10\%, respectively) in four governorates in the Nile delta of Egypt (Qalyubia, Dakahlia, Sharkia, Kafr El Sheikh). A compilation of outbreak sites and sites of previous seroepidemiological studies in egypt are indictaed in Additional file 1.

Seroepidemiological studies could merely give a brief insight into the infection status for a short period in which the study was carried out. Therefore, the need for continuous inspections of the antibody prevalence in susceptible species is highly recommended in endemic areas. This paper presents an overview about the antibody presence in non-vaccinated susceptible hosts including sheep, goats and buffalos from Dakahlia governorate, a vulnerable part for new RVF epidemic in Egypt. Furthermore camel sera from an abattoir near Cairo and from southeast of Egypt, near the border to Sudan, were investigated. Aim of this study was to determine the current status of anti-RVFV antibodies in non-immunized hosts for further evaluating the exposure risk for animal and human health.

\section{Methods}

Animal population, study areas and sample collection

The present seroepidemiological study included a total of 873 non-immunized, apparently healthy animals including small ruminants, buffalos and camels, which were sampled during 2014 to 2015 in different areas of Egypt. Due to the high susceptibility of sheep and their suitability for the use as sentinel animals [9, 29-31], 438 sheep samples from 8 different small holding herds were collected during 2015 (Table 1). All animals were settled in Dakahlia governorate, a central part of the Nile River Delta, in open yard holdings, with movement restrictions in the vicinity (Fig. 1). The number of animals in the flocks varied from 20 to 87 animals (mean $(M)=54.75$; standard deviation $(\mathrm{SD})=23.24$ ). Additionally sheep herd 1 and 2 included a total of 26 goats (17 in herd 1 and 9 in herd 2). Small holders were characterized by keeping less than 50 animals, often in family farming with poor resources, no health management and prevalently with more than one species.

Further ruminant samples were collected from 188 Asian water buffalos (Table 1, Fig. 1). 88 serum samples derived from four small holdings located in Dakahlia governorate (61 samples collected in 2014 and 27 samples in 2015). Small holder flocks included 9 to 31 buffalos $(M=22$; $\mathrm{SD}=$ 8.3). Additional 100 samples were collected from buffalos from a farm in Ismailia governorate, situated in the south eastern of the Nile Delta at the Suez Canal. In general farms are characterized by herd sizes over 50 animals and a good health management and restricted movements of the animals (only to local markets in the country). In this study the sampled farm kept 1200 animals. All buffalos and small ruminants included in this study were born after the last Egyptian RVF epidemic in 2003 and were not imported from other endemic countries.

To investigate the role of camels in Egypt additional samples were collected from this species. Most of the Egyptian camels were imported from Sudan and were kept in quarantine near the border of Sudan in Red Sea governorate after importation (Fig. 1). We investigated 150 of those camel derived sera and additional 71 camel sera taken at an abattoir near Cairo (Table 1).

All blood samples were randomly collected from apparently healthy animals and an informed consent for 
Table 1 Samples ordered by species, holding system, and region

\begin{tabular}{|c|c|c|c|c|c|c|}
\hline Species & Holding & $\begin{array}{l}\text { Herd } \\
\text { number }\end{array}$ & Age & Region & $\begin{array}{l}\text { Number of } \\
\text { samples }\end{array}$ & $\begin{array}{l}\text { Date of sample } \\
\text { collection }\end{array}$ \\
\hline Sheep & Open yard (small holder) & 1 & $2-5$ & Dakahlia Governorate (Aga district) & 87 & April 2015 \\
\hline Goat & & & $2-3$ & & 17 & \\
\hline Sheep & Open yard (small holder) & 2 & $2-10$ & Dakahlia Governorate (Aga district) & 82 & May 2015 \\
\hline Goat & & & & & 9 & \\
\hline Sheep & Open yard (small holder) & 3 & $2-5$ & Dakahlia Governorate (Belkas district) & 50 & May 2015 \\
\hline Sheep & Open yard (small holder) & 4 & $1-4$ & Dakahlia Governorate & 78 & June 2015 \\
\hline Sheep & Open yard (small holder) & 5 & $1-5$ & Dakahlia Governorate & 40 & June 2015 \\
\hline Sheep & Open yard (small holder) & 6 & $2-4$ & Dakahlia Governorate & 49 & June 2015 \\
\hline Sheep & Open yard (small holder) & 7 & $3-7$ & Dakahlia Governorate & 32 & June 2015 \\
\hline Sheep & Open yard (small holder) & 8 & $2-4$ & Dakahlia Governorate & 20 & February 2015 \\
\hline Buffalo & Small holder & 1 & $3-7$ & Dakahlia Governorate (Belkas district) & 31 & 2014 \\
\hline Buffalo & Small holder & 2 & $3-7$ & Dakahlia Governorate & 9 & 2014 \\
\hline Buffalo & Small holder & 3 & $3-7$ & Dakahlia Governorate & 21 & 2014 \\
\hline Buffalo & Small holder & 2 & $3-5$ & Dakahlia Governorate (Belkas district) & 27 & 2015 \\
\hline Buffalo & Farm & 1 & $4-6$ & Ismailia Governorate & 100 & 2015 \\
\hline Camel & Abattoir (El Basatine) & & $5-7$ & Cairo & 71 & 2014 \\
\hline Camel & Imported from Sudan & & $2-7$ & Red Sea Governorate (Halayb and Shalatein) & 150 & 2015 \\
\hline
\end{tabular}

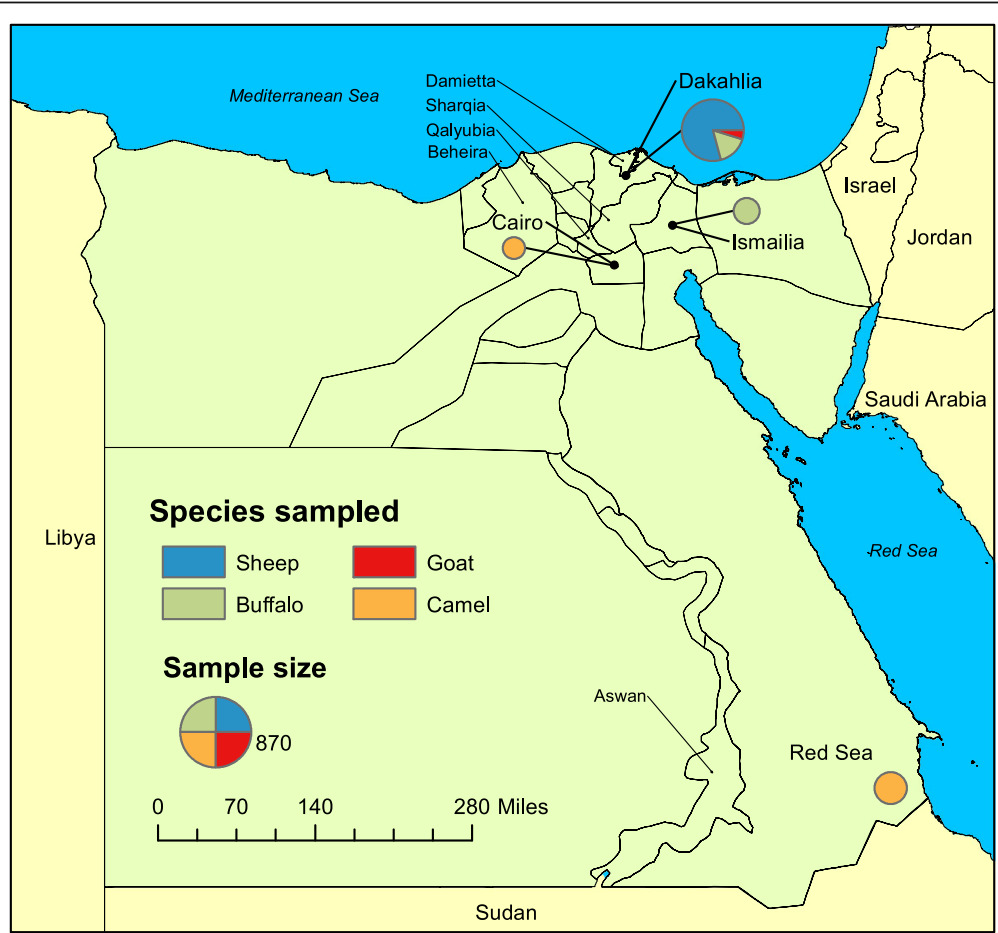

Fig. 1 Region of samples collection. Samples from small ruminants and buffalos from small holders were collected in Dakahlia governorate. Further buffalo samples, derived from farm animals were collected from Ismailia governorate. Camel derived sera were provided from an abattoir near Cairo and from Rea Sea governorate. Previous Egyptian RVFV outbreaks occurred in indicated governorates (Sharqia, Aswan, Qalyubia, Damietta and Beheira) 
RVFV investigation was given by the owners. All procedures were performed in accordance with the principles and specific guidelines presented in the Guidelines for the Care and Use of Agricultural Animals in Research and Teaching, $3^{\text {rd }}$ ed. [32].

Animal specimens were collected under the direction of the Mansoura University, Mansoura, Egypt, within the framework of the project 'Brucellosis, Q-fever and viral hemorrhagic fever infections in Egypt'. The collected blood samples were kept overnight at room temperature to allow blood clotting. On the next day, clear sera were collected and stored at $-20{ }^{\circ} \mathrm{C}$ until shipping. In Germany, the sera were subjected to Gamma radiation (Synergy Health, Radeberg) and were irradiated for $24 \mathrm{~h}$ by $30 \mathrm{k}$ gray. This treatment was carried out to ensure that the examinations can be done under BSL 2 conditions. After radiation, the sera were stored at $-20{ }^{\circ} \mathrm{C}$ until serological examinations.

\section{Serological testing's}

\section{Enzyme linked immunosorbent assay (ELISA)}

Each sample was first analyzed with the commercial ID Screen ${ }^{\circledR}$ RVFV competition multispecies ELISA (ID VET, Montpellier, France) according to the manufacturers' instructions [30]. The cELISA is based on recombinant nucleoprotein and detects anti-RVFV antibodies (both IgM and IgG).

\section{Virus neutralization test (VNT)}

Investigation of neutralizing antibodies of the samples was carried out by VNT, the gold standard for serological RVF analysis. VNT was performed using the RVFV-MP12 vaccine strain according to the OIE terrestrial manual, 2015 [33]. Briefly, each serum samples were run in duplicate and titrated in three steps (1:5, 1:10, $1: 20)$. The diluted virus (100 $\mathrm{TCID}_{50}$ per well) was added to $1: 10$ and $1: 20$ serum dilution, $1: 5$ served as serum control. After $30 \mathrm{~min}$ incubation at $37{ }^{\circ} \mathrm{C}$ and $5 \% \mathrm{CO}_{2}$ $3 \times 10^{5}$ Vero 76 cells (Collection of Cell Lines in Veterinary Medicine, Friedrich-Loeffler-Institut, Germany) per $\mathrm{ml}$ were added to each well. Positive and negative control sera as well as cell and virus controls were included in each test cycle. After six days at $37{ }^{\circ} \mathrm{C}$ and $5 \% \mathrm{CO}_{2}$ cytopathic effects were revealed and the plates were fixed with formalin, colored with crystal violet and the VNT titer was calculated. According to the BehrensKaerber method the neutralizing antibody titer of the samples was defined as the 50\% neutralization dose $\left(\mathrm{ND}_{50}\right)$. Serum samples with $\mathrm{ND}_{50}$ values above 10 were determined as positive; samples with lower titer than 10 were determined as negative. While the endpoint titer was not in focus of interest all sera with a higher $\mathrm{ND}_{50}$ value than 30 were not further diluted and were summarized as $\geq 30$.

\section{Indirect Immunofluorescence assay (IIFA)}

Additional confirmation of positive and inconclusive results in previous tests was performed with an in-house immunofluorescence assay (IIFA) according to a previously published protocol [11]. In short diluted serum samples were added to commercial RVFV immunofluorescence slides from Euroimmun (Lübeck, Germany). After $30 \mathrm{~min}$ reaction time, the slides were washed and the conjugate was added. A donkey anti-sheep IgG Cy3 (Indocarbocyanine)-labelled antibody (Dianova, Hamburg, Germany) was used for small ruminants and a goat anti-bovine IgG Cy3-labelled antibody (Dianova) for buffalo samples, respectively. A polyclonal rabbit-anti-camel antiserum (Bethyl laboratories, Montgomery, TX, USA) was used as a second antibody for camel samples followed by a Cy3-conjugated goat anti-rabbit antibody (Dianova) according to the method described by Jäckel [11]. The slides were evaluated with a fluorescence microscope (Nikon, Tokyo, Japan).

\section{IgM ELISA}

To detect recent infection samples showing positive cELISA results (positive to IgG or IgM) in combination with negative IIFA results (detects only IgG) were further tested with the ID Screen ${ }^{\bullet}$ Rift Valley Fever IgM capture ELISA (ID VET, Montpellier, France) according to the manufacturer's instructions.

\section{Interpretation of the results}

Sera were classified as 'positive' when VNT alone or at least two assays produced consistent positive results. In a limited number of cases, due to low sample volume, application of combined analysis was not possible. Referred to the required serum volume for performing the different test systems, such sera were first tested by IIFA and then, if possible, confirmed by VNT and/or cELISA. If only one test could be carried out, the result of this test was used for classification. Combined test performance with result conclusion was considered to increase the total test accuracy. Positive results indicated seroconversion of the animals after contact to the antigen, independent of the point of exposure.

The true prevalence of each species/herds was calculated using the calculation tool of 'Working in Epidemiology' from the University of Zaragoza [20] (http:// www.winepi.net/uk/index.htm).

\section{Results}

Antibodies against Rift Valley fever virus were detected with three different methods, an approach, which enabled the identification of antibodies against the nucleoprotein in case of competition ELISA, neutralizing antibodies (frequently against the glycoprotein Gn) in case of the VNT and of IIFA reactive antibodies. 
Only two out of 438 sheep samples were tested positive displaying a seroprevalence of $0.46 \%$ (95\% confidence interval [95\%CI:] 0.414-0.5). In addition no seropositive goat was detected. Results from individual tests as well as the data interpretation are shown in Table 2. A detailed analysis of positive samples is shown in Table 3.

Four sera were subjected to IgM capture ELISA to detect recent infections. All sera gave negative results in this test.

Buffalo derived sera gained from four small holders in Dakahlia governorate revealed that 11 out of 88 sera were determined positive corresponding to a seroprevalence of 12.5\% (95\% CI: 11.25-13.75) (Tables 2 and 3). Individual small holding herds showed prevalence of 19.35 (95\%CI: 15.93-22.78), 22.22\% (95\%CI: 22.22-22.22), $14.29 \%$ (95\%CI: $11.09-17.48$ ) and $0 \%$, respectively. In contrast, no positive results were observed in 100 buffalo sera from the farm. The overall seropositivity for 188 buffalo samples was therefore $5.85 \%$ (95\% CI: 2.75-8.95).

Finally also camel sera were subjected to serological analysis. Seven out of 71 sera of animals from the slaughterhouse showed positive results (five of them displayed $\mathrm{ND}_{50}$ values of 30 or higher [Table 3]); however none of the samples from imported camels were determined positive. The corresponding prevalence for camels from abattoir was 9.86\% (95\% CI: $2.92-16.79)$ and 3.17\% (95\% CI: 0.86-5.48) comprised the total camel number. The total seroprevalence of all investigated animals $(n=873)$ was $2.29 \%$ (95\% CI: $1.30-3.28)$.

\section{Discussion}

The seroepidemiological study presented here provided insights into the current RVF antibody status in nonimmunized livestock and enabled a preliminary evaluation of the exposure risk to the virus in susceptible host species.

Sheep are the most susceptible species to RVFV infections [9, 30] and often used as sentinel animals in endemic areas [29, 31]. Therefore the investigation of sheep samples in the Nile Delta, a vulnerable part of Egypt for new RVF epidemics was in the focus of this study. The presence of antibodies against RVFV in sheep samples was very low (0.46\%). Studies conducted 7 years after the large epidemic/epizootic in 1977 encompassing 1714 sheep showed a prevalence of $1.2 \%$ in the governorate of Dakahlia [34]. These results are in line with the finding obtained in this study i.e. 12 years after the last RVF outbreak in Egypt which occurred in 2003.

Unlike to the results stated here, previous reports conducted in the present inter-epidemic period document a relatively higher seropositivity in small ruminants located in the Nile Delta of Egypt. Ramadan, [27] found in 2009 a prevalence of $19.9 \%(n=183$ sheep samples from
Dakahlia governorate) and also the results of Marawan, [28] in year 2012 indicated a considerably higher positivity of $12.3 \%$ ( $n=70$ sheep samples from the same governorate). Further studies in additional Nile Delta governorates showed likewise higher prevalence levels (a total of 17.6\% in Qalyubia, Sharkia and Kafr el Sheikh in 2012; 21.4\% in El Monofia, Beheira and Kafr el Sheikh in 2009/2010 [28, 35]). Deviating prevalence levels in small ruminants examined in 2009 and 2012 as compared to our data for sheep in 2015 indicate that the more recent virus circulation was negligible. Nevertheless, as a) none of these animals was imported and b) animals were transported only locally, a RVFV circulation can be assumed, especially also since all animals were born after the last reported RVFV outbreak.

The significant role of camels in transmission and spread of RVFV was already demonstrated during the Egyptian RVF outbreak in 1997. Due to often rare clinical manifestations in camels and the assumption that camels are less susceptible, camels, imported from other endemic countries in particular can carry the virus [7, 36]. Egypt imports camels for human consumption from endemic countries like Sudan or the Horn of Africa [21]. None of the imported camels included in the here presented study showed a positive result, whereas the collected specimens from abattoir-camels gave a prevalence of $9.86 \%$. Elevated neutralization titers in these camels might suggest an antigen contact quite recently. Unfortunately there was no further information about the history of the origin of the abattoir-camels. Therefore it could not be ruled out, that those animals were previously imported. Previous studies in Egyptian camels during the present inter-epidemic period are conducted in 2009/2010 with 10 camel sera from an abattoir [35] and in 2012 encompassing 100 camels from Qalyubia governorate [28]. Likewise no further information about the origin of the animals is given in these reports. Both studies detected no antibodies in Egyptian camels. Only $10 \%$ of imported animals are tested against RVFV antibodies directly after the import as a routine disease control. Positive results in camels in this study were supposed to be imported positive animals from other endemic countries. The risk to import viremic animals should not be neglected; hence continuing investigations on the role of camels should be in focus of further investigations.

Buffalos presumably play a role as amplifying hosts during inter-epidemic periods. Antibodies against RVFV were detected in several studies in different African countries during inter-epidemic times (e.g. prevalence rates of 21, 15.6 and $12.5 \%$ in South Africa, Kenya and Botswana respectively [37-39]).

The analyzed buffalo sera in this study showed also a relatively slight prevalence of $5.85 \%$. This finding corresponds to results obtained from Horton in 2009 [35], 
Table 2 Serological analysis of Egyptian serum samples from small ruminants, buffalos and camels with cELISA (ID Vet Screen Rift Valley Fever competition ELISA (multispecies), indirect immunofluorescence assay (IIFA) and virus neutralization test (VNT) (A) Results grouped into species. Result conclusion (B). Detailed prevalence of herds is shown in part (C)

\begin{tabular}{|c|c|c|c|c|c|c|c|c|c|c|c|}
\hline \multicolumn{12}{|l|}{ (A) } \\
\hline \multirow[b]{2}{*}{ Species } & \multicolumn{4}{|c|}{ ID screen ${ }^{\circledast}$ multispecies competition ELISA } & \multicolumn{4}{|c|}{ Virus neutralization test } & \multicolumn{3}{|c|}{ Immunofluorescence } \\
\hline & Tested & Positive & Doubtful & Negative & Tested & Positive & Negative & Tested & Positive & Doubtful & Negative \\
\hline Sheep & 417 & 3 & 1 & 413 & 381 & 0 & 381 & 88 & 3 & 3 & 82 \\
\hline Goat & 26 & 0 & 0 & 26 & 26 & 0 & 26 & n.t. & n.t. & n.t. & n.t. \\
\hline Buffalo (small holder) & 78 & 8 & 0 & 70 & 56 & 2 & 54 & 32 & 8 & 0 & 24 \\
\hline Buffalo (farms) & 95 & 1 & 0 & 94 & 88 & 0 & 88 & 16 & 0 & 0 & 16 \\
\hline Camels abattoir & 1 & 1 & 0 & 0 & 59 & 6 & 53 & 71 & 2 & 0 & 69 \\
\hline $\begin{array}{l}\text { Camels imported from } \\
\text { Sudan }\end{array}$ & 130 & 0 & 0 & 130 & 121 & 0 & 121 & 20 & 0 & 0 & 20 \\
\hline Total: & 747 & 13 & 1 & 733 & 731 & 8 & 723 & 227 & 13 & 3 & 211 \\
\hline \multicolumn{12}{|l|}{ (B) } \\
\hline Result conclusion & $\begin{array}{l}\text { animals in the } \\
\text { herds }\end{array}$ & tested & positive & inconclusive & negative & $\begin{array}{l}\text { prevalence } \\
(\%)\end{array}$ & $95 \% \mathrm{Cl}$ & & & & \\
\hline Sheep & 440 & 438 & 2 & 1 & 435 & 0.46 & $0.41-0.5$ & & & & \\
\hline Goat & 17 & 26 & 0 & 0 & 26 & 0.00 & $\begin{array}{l}0.00- \\
0.00\end{array}$ & & & & \\
\hline Buffalo (small holder) & 91 & 88 & 11 & 0 & 77 & 12.5 & $\begin{array}{l}11.25- \\
13.75\end{array}$ & & & & \\
\hline Buffalo (farm) & 1200 & 100 & 0 & 0 & 100 & 0.00 & $0-2.83$ & & & & \\
\hline Came I (abattoir) & & 71 & 7 & 0 & 64 & 9.86 & $\begin{array}{l}2.92- \\
16.79\end{array}$ & & & & \\
\hline Imported camel & & 150 & 0 & 0 & 150 & 0.00 & $\begin{array}{l}0.00- \\
0.00\end{array}$ & & & & \\
\hline \multicolumn{12}{|l|}{ (C) } \\
\hline $\begin{array}{l}\text { Results in individual } \\
\text { herds }\end{array}$ & $\begin{array}{l}\text { animals in the } \\
\text { herds }\end{array}$ & tested & positive & $\begin{array}{l}\text { prevalence } \\
(\%)\end{array}$ & $95 \%$ C I & & & & & & \\
\hline sheep herd 4 & 78 & 78 & 1 & 1.28 & $\begin{array}{l}1.28- \\
1.28\end{array}$ & & & & & & \\
\hline sheep herd 5 & 42 & 40 & 1 & 2.5 & $\begin{array}{l}1.44- \\
3.56\end{array}$ & & & & & & \\
\hline buffalo small holder 1 & 33 & 31 & 6 & 19.35 & $\begin{array}{l}15.93- \\
22.78\end{array}$ & & & & & & \\
\hline buffalo small holder 2 & 9 & 9 & 2 & 22.22 & $\begin{array}{l}22.22- \\
22.22\end{array}$ & & & & & & \\
\hline buffalo small holder 3 & 22 & 21 & 3 & 14.29 & $\begin{array}{l}11.09- \\
17.48\end{array}$ & & & & & & \\
\hline
\end{tabular}

which included 153 buffaloes from the Muneeb abattoir in central Egypt, who reported a prevalence of 3\% and also to the results from Marawan, 2012, [28] who obtained a prevalence of $9.8 \%$ in 102 buffalo sera. Interestingly, there was a striking difference of the prevalence levels for different holding systems: it ranged from $0 \%$ in buffalo on the farm compared to animals owned by small holders (12.5\%). Individual small buffalo holdings showed seroprevalences of up to $22 \%$, which might be due to a lower health status of the animals in small holding flocks. Additionally, farmed buffalos were located in Ismailia governorate. Ismailia is located marginal to the east lower Nile Delta, which could be a reason for lower presence of transmission of the virus to naïve animals.

Main vectors for the RVFV transmission in Egypt are mosquitos of genus Culex [40]. In 2009 Ramadan [27] collected these mosquitos from Dakahlia governorate and found $11.1 \%$ positive encompassing 806 mosquitos in 13 pools which indicates virus maintenance in the country. Due to more elaborate health management measures in larger farms, which might include also vector control programs, natural RVFV infections by Culex mosquitos in these farms are less likely as compared to small holder husbandry. We found a prevalence of $18 \%$ 
Table 3 Individual positive results of Egyptian serum samples from small ruminants, buffalos and camels with cELISA (ID Vet Screen Rift Valley Fever competition ELISA (multispecies), indirect immunofluorescence assay (IIFA) and virus neutralization test (VNT)

\begin{tabular}{|c|c|c|c|c|c|c|c|c|}
\hline \multicolumn{3}{|c|}{ Sample number } & \multirow[t]{2}{*}{ Herd } & \multirow{2}{*}{$\begin{array}{l}\text { Age } \\
\text { (years) }\end{array}$} & \multirow[t]{2}{*}{ ID vet cELISA S/N\% } & \multirow[t]{2}{*}{ IIFA } & \multirow{2}{*}{$\begin{array}{l}\text { VNT } \\
\text { ND50 value* }\end{array}$} & \multirow{2}{*}{$\begin{array}{l}\text { Result } \\
\text { conclusion }\end{array}$} \\
\hline Sheep & & & & & & & & \\
\hline EG & 12 & 15/OV & 1 & $2-7$ & 32,82 & negative & negative & negative \\
\hline EG & 247 & 15/OV & 4 & $1-4$ & 17,79 & ++ & negative & positive \\
\hline EG & 256 & $15 / \mathrm{OV}$ & 4 & $1-4$ & 16,24 & negative & negative & negative \\
\hline EG & 282 & 15/OV & 4 & $1-4$ & 49,48 & negative & negative & negative \\
\hline EG & 299 & 15/OV & 5 & $1-5$ & not tested & $+/-$ & negative & negative \\
\hline EG & 304 & 15/OV & 5 & $1-5$ & not tested & $+/-$ & negative & negative \\
\hline EG & 321 & 15/OV & 5 & $1-5$ & not tested & $+/-$ & not tested & inconclusive \\
\hline EG & 328 & 15/OV & 5 & $1-5$ & not tested & + & not tested & positive \\
\hline EG & 394 & $15 / \mathrm{OV}$ & 7 & $1-5$ & not tested & ++ & negative & inconclusive \\
\hline \multicolumn{9}{|c|}{ Buffalo - small holder } \\
\hline EG & 4 & $14 / \mathrm{BF}$ & 1 & $3-7$ & 88,81 & negative & 10 & positive \\
\hline EG & 9 & 14/BF & 1 & $3-7$ & 4,90 & not tested & not tested & positive \\
\hline EG & 14 & 14/BF & 1 & $3-7$ & 66,06 & negative & 20 & positive \\
\hline EG & 15 & 14/BF & 1 & $3-7$ & 4,03 & ++ & not tested & positive \\
\hline EG & 20 & 14/BF & 1 & $3-7$ & 3,88 & $++(+)$ & not tested & positive \\
\hline EG & 23 & 14/BF & 1 & $3-7$ & 3,65 & ++ & not tested & positive \\
\hline EG & 34 & 14/BF & 2 & $3-7$ & 4,01 & $++(+)$ & not tested & positive \\
\hline EG & 38 & 14/BF & 2 & $3-7$ & 18,46 & $++(+)$ & not tested & positive \\
\hline EG & 41 & 14/BF & 3 & $3-7$ & 37,71 & + & not tested & positive \\
\hline EG & 42 & 14/BF & 3 & $3-7$ & 10,88 & ++ & not tested & positive \\
\hline EG & 53 & 14/BF & 4 & $3-7$ & not tested & $(+)$ & not tested & positive \\
\hline \multicolumn{9}{|c|}{ Buffalo - farms } \\
\hline EG & 59 & 15/BF & 1 & $4-6$ & 8,80 & negative & negative & Negative \\
\hline \multicolumn{9}{|c|}{ Camel - abattoir } \\
\hline EG & 3 & $14 / \mathrm{CM}$ & abattoir & $5-7$ & not tested & negative & 10 & positive \\
\hline EG & 4 & $14 / \mathrm{CM}$ & abattoir & $5-7$ & not tested & negative & $>30$ & positive \\
\hline EG & 18 & $14 / \mathrm{CM}$ & abattoir & $5-7$ & not tested & negative & $>30$ & positive \\
\hline EG & 32 & $14 / \mathrm{CM}$ & abattoir & $5-7$ & 5,76 & ++ & $>30$ & positive \\
\hline EG & 46 & $14 / \mathrm{CM}$ & abattoir & $5-7$ & not tested & negative & $>30$ & positive \\
\hline EG & 58 & 14/CM & abattoir & $5-7$ & not tested & ++ & not tested & positive \\
\hline EG & 67 & 14/CM & abattoir & $5-7$ & not tested & negative & $>30$ & positive \\
\hline
\end{tabular}

CELISA results with a percentage of inhibition lower than 40 were defined as positive, between 40 and $50 \%$ as inconclusive and results higher than a percentage of inhibition of 50 were defined as negative. IIFA results were defined from low (+) to strong (+++) straining, or as inconclusive $(+/-)$. ND 50 values lower than 10 were defined as negative when performing VNT. Titers higher than $\mathrm{ND}_{50}$ values of 20 indicate a strong immune response

Positive and inconclusive findings and results are indiciated in italics

in buffalos sampled in $2014(n=61)$, whereas the small holder buffalos from $2015(n=27)$ showed only negative results. It would be of interest, to study in more detail, to which extent differences in the holding systems can influence the general infection risk for the animals. According to the farmer's documentation the buffalos were not imported from other endemic countries. Moreover buffalos were restricted in their movements and were only transported to local markets. Therefore also the data obtained for buffalos (similar to those found in small ruminants) suggests an active virus transmission in Dakahlia governorate during the present interepidemic period in Egypt.

Altogether, a comprehensive and well-designed surveillance program allows the early detection of first indications for the transition from endemic to epidemic cycle. Such a surveillance program should include investigations on the serological status of all susceptible animals in areas 
at risk, the monitoring of vectors and the intensification of import controls for animals coming from endemic countries.

\section{Conclusions}

The examination of 873 sera collected from sheep, goats, camels and buffalos gave an insight into the anti-RVFV antibody situation in Egypt during 2014/2015. All animals included in this study were born after the last Egyptian RVF epidemic in 2003 and, as to farmer's records, buffalos and sheep were not imported from other endemic countries. Therefore the antibody prevalence observed in buffalos and sheep were results of cryptic virus transmissions during the present inter-epidemic period. Based on a general low prevalence in all investigated animal species, a currently low level of circulating virus in the investigated areas can be assumed. Due to the general lack of detailed data about the role of camels for cryptic virus transmissions in Egypt further investigations are needed.

Assuming the high susceptibility of small ruminants to RVF, our data indicate, that small ruminants in Egypt are not the main source of inter-epidemic virus circulation, which means infections of alternative animal hosts that are less receptive to clinical manifestations.

\section{Additional file}

Additional file 1: Table S1. Comparison of outbreak sites and sites of previous seroepidemiological studies in Egypt. (DOC $18.7 \mathrm{~kb}$ )

\section{Acknowledgement}

The authors would like to thank Timo Homeier-Bachmann for preparation of the map.

\section{Funding}

We thank the German Office for Foreign Affairs for funding this study (German Partnership Program for Excellence in Biological and Health Security).

\section{Availability of data and material}

All the data supporting our findings are included in the manuscript.

\section{Authors' contributions}

$M G, M E A, M E D$ and MEB realized the collection of well-documented ruminant sera. All authors read and approved the final manuscript.

\section{Competing interests}

The authors declare that they have no competing interests.

\section{Consent for publication}

Not applicable.

\section{Ethics approval and consent to participate}

The animals were sampled under the direction of the Mansoura University, Mansoura, Egypt, within the framework of the project 'Brucellosis, Q-fever and viral hemorrhagic fever infections in Egypt' [IIA6] during 2013 to 2015. Brucellosis, Qfever and viral hemorrhagic fever infection like the Rift Valley fever virus are priority diseases for control and eradication by the Government of Egypt. Informed consents for RVFV investigations were given by all owners. All procedures were performed in accordance with the principles and specific guidelines presented in the Guidelines for the Care and Use of Agricultural Animals in Research and Teaching, $3^{\text {rd }}$ ed.

\section{Publisher's Note}

Springer Nature remains neutral with regard to jurisdictional claims in published maps and institutional affiliations.

\section{Author details}

${ }^{1}$ Institute of Novel and Emerging Infectious Diseases,

Friedrich-Loeffler-Institut, Südufer 10, 17493 Greifswald - Isle of Riems, Germany. ${ }^{2}$ Department of Hygiene and Zoonoses, Faculty of Veterinary Medicine, Mansoura University, Mansoura 35516, Egypt. ${ }^{3}$ Department of Internal Medicine and Infectious Diseases, Faculty of Veterinary Medicine, Mansoura University, Mansoura 35516, Egypt. ${ }^{4}$ Animal Health Research Institute-Mansoura Provincial Laboratory, Mansoura, Egypt. ${ }^{5}$ Faculty of Veterinary Medicine, Mansoura University, Mansoura, Egypt.

Received: 4 June 2016 Accepted: 17 March 2017

Published online: 05 April 2017

\section{References}

1. Easterday BC. Rift Valley fever. Adv Vet Sci. 1965;10:65-127.

2. Pepin M, et al. Rift Valley fever virus (Bunyaviridae: Phlebovirus): an update on pathogenesis, molecular epidemiology, vectors, diagnostics and prevention. Vet Res. 2010;41(6):61.

3. Daubney R, Hudson JR, Garnham PC. Enzootic hepatitis or rift valley fever. An undescribed virus disease of sheep cattle and man from east africa. J Pathol. 1931;34:545-79.

4. Findlay GM, Daubney R. The virus of Rift Valley fever or enzootic hepatitis. Lancet. 1931;218(5651):1350-1.

5. Bird BH, et al. Rift Valley fever. J Am Vet Med Assoc. 2009;234(7):883-93.

6. Elliott RM. Emerging viruses: the Bunyaviridae. Mol Med. 1997;3(9):572-7.

7. Linthicum KJ, Britch SC, Anyamba A. Rift Valley Fever: an emerging mosquito-borne disease. Annu Rev Entomol. 2016;61:395-415.

8. Madani TA, et al. Rift Valley fever epidemic in Saudi Arabia: epidemiological, clinical, and laboratory characteristics. Clin Infect Dis. 2003;37(8):1084-92.

9. Chevalier $\mathrm{V}$, et al. Rift Valley fever - a threat for Europe? Eurosurveillance. 2010;15(10):18-28

10. Balkhy HH, Memish ZA. Rift Valley fever: an uninvited zoonosis in the Arabian peninsula. Int J Antimicrob Agents. 2003;21(2):153-7.

11. Jäckel $\mathrm{S}$, et al. Molecular and serological studies on the Rift Valley fever outbreak in Mauritania in 2010. Transbound Emerg Dis. 2013;60(2):31-9.

12. Himeidan YE, et al. Recent outbreaks of Rift Valley fever in East Africa and the Middle East. Front Public Health. 2014;2:169.

13. Pienaar NJ, Thompson PN. Temporal and spatial history of Rift Valley fever in South Africa: 1950 to 2011. Onderstepoort J Vet Res. 2013;80(1):384.

14. Aradaib IE, et al. Rift Valley fever, Sudan, 2007 and 2010. Emerg Infect Dis. 2013:19(2):246-53

15. Meegan JM. The Rift Valley fever epizootic in Egypt 1977-78. 1. Description of the epizzotic and virological studies. Trans R Soc Trop Med Hyg. 1979; 73(6):618-23.

16. Meegan JM, Hoogstraal $H$, Moussa MI. An epizootic of Rift Valley fever in Egypt in 1977. Vet Rec. 1979;105(6):124-5.

17. Darwish $M$, Hoogstraal $H$. Arboviruses infecting humans and lower animals in Egypt: a review of thirty years of research. J Egypt Publ Hlth Assoc. 1981;56:1-112.

18. Gerdes GH. Rift Valley fever. Rev Sci Tech. 2004;23(2):613-23.

19. Arthur RR, et al. Recurrence of Rift Valley fever in Egypt. Lancet. 1993;342:1149-50.

20. Abu-Elyazeed $R$, et al. Prevalence of anti-rift-valley-fever IgM antibody in abattoir workers in the Nile delta during the 1993 outbreak in Egypt. Bull World Health Organ. 1996;74(2):155-8.

21. Kamal AS. Observations on Rift Valley fever virus and vaccines in Egypt. Virol J. 2011;8(1):532.

22. Hanafi HA, et al. Virus isolations and high population density implicate Culex antennatus (Becker) (Diptera: Culicidae) as a vector of Rift Valley fever virus during an outbreak in the Nile Delta of Egypt. Acta Trop. 2011;119(2-3):119-24.

23. Abd el-Rahim IH, Abd el-Hakim U, Hussein M. An epizootic of Rift Valley fever in Egypt in 1997. Rev Sci Tech. 1999;18(3):741-8.

24. Drake JM, Hassan AN, Beier JC. A statistical model of Rift Valley fever activity in Egypt. J Vector Ecol. 2013;38(2):251-9.

25. Gerdes GH. Rift Valley fever. Vet Clin North Am Food Anim Pract. 2002; 18(3):549-55. 
26. Roger $\mathrm{M}$, et al. Evidence for circulation of the Rift Valley fever virus among livestock in the union of Comoros. PLoS Negl Trop Dis. 2014;8(7):e3045.

27. Ramadan HHE. Epidemiological study on Rift Valley fever as a zoonotic viral disease transmitted by arthropod and its public health importance (thesis). In: Faculty of Veterinary Medicine, Department of Hygiene and Zoonoses. Mansoura: Mansoura University; 2009.

28. Marawan AM, et al. Epidemiological studies on Rift Valley fever disease in Egypt. Benha Vet Med J. 2012;23(1):171-84.

29. Al-Qabati AG, Al-Afaleq Al. Cross-sectional, longitudinal and prospective epidemiological studies of Rift Valley fever in Al-Hasa Oasis, Saudi Arabia. J Anim Vet Adv Vet Sci. 2010;9(2):258-65.

30. Kortekaas J, et al. European ring trial to evaluate ELISAs for the diagnosis of infection with Rift Valley fever virus. J Virol Methods. 2012;187(1):177-81.

31. Lichoti JK, et al. Detection of Rift Valley fever virus interepidemic activity in some hotspot areas of kenya by sentinel animal surveillance, 2009-2012. Vet Med Int. 2014;2014:379010.

32. FASS. Guide for the Care and Use of Agricultural Animals in Research and Teaching, Third Edition, January 2010. 2010 [cited 2016 1. April]; Available from: https://www.aaalac.org/about/Ag_Guide_3rd_ed.pdf.

33. OIE. Manual of Diagnostic Tests and Vaccines for Terrestrial Animals. 2015 [cited 2016 6. April]; Available from: http://www.oie.int/manual-ofdiagnostic-tests-and-vaccines-for-terrestrial-animals/.

34. Botros BAM, et al. Rift Valley fever in Egypt 1986. Surveillance of sheep flocks grazing in the northeast Nile Delta. J Trop Med Hyg. 1988;91(4):183-8.

35. Horton KC, et al. Serosurvey for zoonotic viral and bacterial pathogens among slaughtered livestock in Egypt. Vector Borne Zoonotic Dis. 2014;14(9):633-9.

36. Davies FG, Koros J, Mbugua H. Rift Valley fever in Kenya: the presence of antibodies to the virus in camels (Camelus dromedarius). J Hyg (Lond). 1985;94:241-4

37. LaBeaud AD, et al. Rift Valley fever virus infection in African buffalo (Syncerus caffer) herds in rural South Africa: evidence of interepidemic transmission. Am J Trop Med Hyg. 2011;84(4):641-6.

38. Evans $A$, et al. Prevalence of antibodies against Rift Valley fever virus in Kenyan wildlife. Epidemiol Infect. 2008;136(9):1261-9.

39. Jori $F$, et al. Serological evidence of Rift Valley fever circulation in domestic cattle and African buffalo in Northern Botswana (2010-2011). Fronties Vet Sci. 2015;2:63.

40. Zayed $A B$, et al. Mosquitoes and the environment in Nile delta villages with previous Rift Valley fever activity. J Am Mosq Control Assoc. 2015;31(2):139-48.

\section{Submit your next manuscript to BioMed Central and we will help you at every step:}

- We accept pre-submission inquiries

- Our selector tool helps you to find the most relevant journal

- We provide round the clock customer support

- Convenient online submission

- Thorough peer review

- Inclusion in PubMed and all major indexing services

- Maximum visibility for your research

Submit your manuscript at www.biomedcentral.com/submit 